\title{
Modal Intelektual Dan Kinerja Perusahaan \\ (Studi pada perusahaan yang terdaftar di Bursa Efek Indonesia periode 2009 s/d 2012)
}

Oleh:

\author{
Novi S Budiarso
}

\author{
Fakultas Ekonomi dan Bisnis \\ Universitas Sam Ratulangi Manado \\ Email: novi_sbudiarso@yahoo.com
}

\begin{abstract}
ABSTRAK
Penelitian ini mengeksplorasi bagaimana karakteristik modal intelektual memberikan kontribusi terhadap keuntungan kompetitif. Tujuan utama dari penelitian ini adalah menguji hubungan antara efisiensi dari Value Added Intellectual Coeficient (VAIC ${ }^{T M}$ )yang terdiri atas komponen sumber daya perusahaan, physical capital(VACA), human capital(VAHU) and structural capital(STVA)dan tradisional dimensi dari kinerja keuangan perusahaan: Asset Turn Over. Hasil penelitian menunjukan bahwa secara parsial modal intelektual $\left(V A I C^{T M}\right)$, modal fisik tidak signifikan mempengaruhi kinerja perusahaan. Secara simultan, modal fisik, modal karyawan dan modal structural mempengaruhi kinerja perusahaan.Hasil empiris menyatakan bahwa telah terjadi pergeseran pemikiran tentang struktur baru dan proses penjunjang produktivitas aset perusahaan. Modal karyawan, merupakan indicator yang paling signifikan bagi $V A I C^{T M}$ dan kinerja perusahaan, berperan sebagai penggerak utama untuk pencipataan nilai.
\end{abstract}

Kata Kunci: Modal Intelektual, Kinerja Perusahaan

\section{ABSTRACT}

This study explores the way in which intellectual capital characteristics contribute towards a competitive advantage. The principal purpose of this study was to investigate the association between the efficiency ofValue Added Intellectual Coeficient (VAIC ${ }^{T M}$ ) by the major components of a firm's resource base, physical capital(VACA), human capital(VAHU) and structural capital(STVA) and traditional dimensions offinancial company's performance:Asset Turn Over. The findings show that:as partial,intellectual capital (VAIC $\left.{ }^{T M}\right)$, physical capital not significantly influences to company's performance.. Simultaneously, physical capital, human capital, structural capital influences company's performance. The empirical findings suggest thattransition in thinking about a new structure and process supporting a company's productive assets. Human capital, remains the most significant indicator for VAIC ${ }^{T M}$ and financial company's performance, role as principal driver for value creation.

Keywords: Intelectual Capital, Firm Performance 


\section{PENDAHULUAN}

\subsection{Latar Belakang}

Konsep ekonomi manajemen pengetahuan (knowledge based economy) memiliki peranan yang penting dalam hal manajemen strategikdan pengembangan modal intelektual.Manajemen pengetahuan bukan hanya deskripsi tentang ekonomi berdasarkan teknologi tingkat tinggi tapi lebih dari itu menjabarkan sumber daya yang merupakan sumber dari keuntungan kompetitif suatu perusahaan. Peranan modal intelektual sebagai penggerak yang menghasilkan nilai (value creation) perusahaan merupakan hal penting dalam mencapai keuntungan kompetitif. Sedangkan pengetahuan tak berwujud merupakan hal utama dalam proses menghasilkan nilai.

Edvinsson dan Malone (1997) menyatakan hal menarik terkait dengan kegunaan modal intelektual sebagai alat untuk menentukan nilai perusahaan,bahwa faktor utama pertumbuhan perusahaan adalah nilai buku perusahaan. Nilai pasar perusahaan terdiri dari modal keuangan dan "ada hal lain". Modal keuangan merujuk pada nilai buku perusahaan dan dibentuk oleh keuangan perusahaan dan aset fisik. Sedangkan hal lain merujuk pada modal intelektual perusahaan yang didefinisikan sebagai sumber daya yang dihasilkan dari pembelajaran internal dan pengembangan dari pengembangan hubungan yang memiliki nilai.

Motivasi penelitian ini adalah untuk mengetahui komponen-komponen modal intelektual, dan komponen yang mana dari modal intelektual yang dianggap memiliki nilai oleh perusahaan perdagangan, jasa dan investasi yang terdaftar di BEI. Serta bagaimana modal intelektual di deskripsikan oleh perusahaan dalam laporan keuangan tradisional dan meneliti peran modal intelektual sebagai penghasil nilai (value creation) dan menjadikan keuntungan kompetitif perusahaan.

Penelitian ini bertujuan untuk mengetahui apa nilai informasi dalam laporan keuangan tradisional sehubungan dengan penggerak yang menghasilkan nilai? Apakah perusahaan yang terdaftar di Bursa Efek Indonesia menganggap modal intelektual adalah nilai penggerak guna mencapai profitabilitas perusahaan dan menuju keunggulan kompetitif dan memberikan kontribusi terhadap kinerja perusahaan? Karakteristik modal intelektual yang mana yang dinilai oleh perusahaan yang terdaftar di Bursa Efek Indonesia sebagai keuntungan kompetitif dan mengapa karakteristik tersebut yang dipilih?

Kontribusi penelitian ini adalah perusahaan-perusahaan bisa memahami karakteristik dari modal intelektual yang membutuhkan perhatian guna peningkatan kinerja dan sebaliknya perusahaan bisa mendapatkan informasi mengenai komponen modal intelektual yang merupakan penggerak utama atau pencipta nilai perusahaan. Selanjutnya hal ini bisa diaplikasikan pada strategi pengelolaan sumber daya perusahaan guna mendapatkan keuntungan kompetitif.

\section{LANDASAN TEORI \\ 2.1.Kajian Teoritis \\ 2.1.1. Modal Intelektual}

Bozzollan et al. (2003) menyatakan modal intelektual adalah keseluruhan informasi yang berguna untuk investor dan analis. Dilain pihak Brennan (2001) mendefinisikan modal intelektual adalah pengetahuan yang ditransfer untuk menghasilkan nilai aset yang tinggi guna meningkatkan nilai perusahaan. Selanjutnya Brennan menyatakan bahwa nilai dari modal intelektual adalah perbedaan antara nilai pasar dengan nilai buku perusahaan. Abeysekera dan Guthrie (2005) mendefinisikan modal intelektual adalah modal yang tidak diperhitungkan dalam sistem akuntansi tradisional, bisa dinyatakan bahwa nilai pasar perusahaan dipengaruhi oleh 
beberapa faktor, beberapa diantaranya bisa dikontrol dan lainnya tidak bisa dikontrol oleh perusahaan.

Untuk tujuan analisis dan interpretasi beberapa literatur membagi modal intelektual ke dalam beberapa kategori. Edvinsson (1997)dan Edvinsson dan Malone (1997) menghubungkan klasifikasi modal intelektual dengan struktur nilai pasar Skandia. Model pelaporan modal intelektual ini disebut dengan Skandia Navigator, yang menyatakan nilai pasar perusahaan bisa diklasifikasikan menjadi modal keuangan dan modal intelektual. Selanjutnya modal intelektual dibagi atas modal karyawan (human capital) dan modal struktural (structural capital). Structural capital kemudian dibagi menjadi customer capital dan organizational capital. Dan organizational capital dibagi menjadi innovation capital dan process capital. Model ini terdiri atas 5 (lima) area fokus: keuangan, pelanggan, proses, pembaharuan dan pengembangan, dan modal karyawan. Area fokus ini menggambarkan masa lalu (financial focus), saat ini (customer focus, process focus dan human focus) dan masa depan perusahaan (renewal dan development focus). Menurut model ini faktor tersembunyi (hidden factors) dari karyawan dan struktural ketika digabungkan merupakan modal intelektual. Konstruk ini juga diadopsi oleh Organization for Economic Co-Operation and Development (OECD).

Human capital didefinisikan sebagai kombinasi pengetahuan, keahlian, inovasi dan kemampuan pekerja perusahaan secara individual untuk menyelesaikan tugasnya. Human capital juga termasuk nilai-nilai,kebudayaan dan filosofi. Human capital tidak bisa dimiliki oleh perusahaan. Structural capital adalah hardware, software, databases, struktur organisasi, paten, trademarks dan kemampuan organisasi yang mendukung produktivitas pekerja. Structural capital juga menyajikan modal pelanggan, hubungan yang dibangun dengan pelanggan kunci. Tidak seperti human capital, structural capital bisa dimiliki perusahaan dan karenanya bisa diperjualbelikan. Modal intelektual adalah penggabungan atas human dan structural capital.

Value Added Intellectual Coefficient ( VAIC $^{\mathrm{TM}}$ ) merupakan salah satu pengukurandengan metode tidak langsung untuk mengukur seberapa dan bagaimana efisiensi modalintelektual dan modal karyawan menciptakan nilai yang berdasar pada hubungan tigakomponen utama, yaitu capital employed, human capital, dan structural capital. Model ini mengindikasikan kemampuanintelektual organisasi yang dapat dianggap sebagai Business Performance Indicator.

Metode VAICTM, dikembangkan oleh Pulic (1998) dan didesain untuk menyajikaninformasi tentang value creation efficiency dari aset berwujud (tangible asset) dan aset tidak berwujud (intangible assets) yang dimiliki perusahaan. Model ini dimulai dengankemampuan perusahaan untuk menciptakan value added (VA). Value added adalah indikator paling objektif untuk menilai keberhasilan bisnis dan menunjukkan kemampuan perusahaandalam penciptaan nilai (value creation),Pulic(1998). VAdihitung sebagai selisih antaraoutput dan input Pulic(1998).

\subsubsection{Resource Based View (RBV)}

RBV merupakan teori yang menyatakan bagaimana sumber daya berhubungan dengan strategi perusahaan. perusahaan sebagai kumpulan sumber daya dan kemampuan. Pandangan ini didasarkan pada asumsi bahwa perbedaan sumber daya dan kemampuan perusahaan dengan pesaing akan memberikan keunggulan kompetitif.Ketika sumber daya perusahaan menambah nilai perusahaan, langka atau unik dan biaya yang besar jika ditiru dan tidak bisa disubstitusi, RBV bisa digunakan sebagai evaluasi terhadap potensial dari strategi alternative yang dihadapi perusahaan,Barney(2001).

Wenerfelt (1984) menjabarkan kegunaan analisis perusahaan dari sisi sumber daya dibandingkan dari sisi produk. Melihat sumber daya perusahaan sebagai pemicu utama dari kompetitif dan performa perusahaan. 
Sumber daya bisa didefinisikan sebagai aset berwujud dan tidak berwujud yang memiliki hubungan erat dengan perusahaan. Menurut RBV, perusahaan mendapatkan keuntungan kompetitif dan performa superior melalui penggabungan dan penggunaan berikutnya dari strategi asset-aset yang vital guna keuntungan kompetitif dan performa keuangan yang kuat.

\subsubsection{Stakeholder Theory}

Menurut Gutrie (2001) teori ini mengharapkanmanajemen perusahaan melaporkan aktivitas-aktivitas perusahaan kepadapara stakeholder, yang berisi dampak aktivitas-aktivitas tersebut padaperusahaan mereka, meskipun nantinya mereka memilih untuk tidakmenggunakan informasi tersebut. Teori ini menganggap akuntabilitasorganisasional tidak hanya terbatas pada kinerja ekonomi atau keuangansaja, sehingga perusahaan perlu melakukan pengungkapan tentangintellectual capital atau modal intelektual lebih dari yang diharuskan olehbadan yang berwenang.

Kelompok stakeholder inilah yang menjadi pertimbangan utamabagi perusahaan dalam mengungkapkan dan atau tidak mengungkapkaninformasi di dalam laporan keuangan, sehingga perusahaan akanberusaha untuk mencapai kinerja optimal seperti yang diharapkan olehstakeholder Ulum(2008). Salah satu faktor yang mempengaruhimodal intelektualdalam laporan keuangan adalah kinerjaintellectual capital, semakin baik kinerja modal intelektualdalam suatuperusahaan maka akan semakin tinggi tingkat pengungkapannya dalamlaporan keuangan sehingga dapat meningkatkan kepercayaan para stakeholder terhadap perusahaan.

Ketika manajer mampu mengelola organisasi secara maksimal makaPenciptaan nilai (value creation)yang dihasilkan akan semakin baik. Penciptaan nilai yang dimaksud adalah pemanfaatan seluruh potensi yangdimiliki perusahaan, baik modal karyawan (human capital), aset fisik (physicalcapital), maupun modal struktural (structural capital). Pengelolaan yang baik atas seluruhini akan menciptakan value added bagi perusahaan yang kemudian dapat mendorong kinerja keuangan perusahaan untuk kepentinganstakeholder, Ulum (2009).

Dalam konteks untuk menjelaskan tentang konsep modal intelektual, teori stakeholder harus dipandang dari dua bidang, yaitu bidang etika (moral) dan bidang manajerial. Bidang etika berargumen bahwa seluruh stakeholder memiliki hak untuk diperlakukan secara adil oleh organisasi, dan manajer harus mengelola organisasi untuk keuntungan seluruh stakeholder Deegan(2004). Ketika manajer mampu mengelola organisasi secara maksimal, khususnya dalam upaya penciptaan nilai bagi perusahaan, maka itu artinya manajer telah memenuhi aspek etika dari teori ini. Penciptaan nilai dalam konteks ini adalah dengan memanfaatkan seluruh potensi yang dimiliki perusahaan, baik karyawan, aset fisik, maupun struktural. Pengelolaan yang baik atas seluruh potensi ini akan menciptakan value added bagi perusahaan yang kemudian dapat mendorong kinerja keuangan perusahaan untuk kepentingan stakeholder.Bidang manajerial dari teori stakeholder berpendapat bahwa kekuatan stakeholder untuk mempengaruhi manajemen korporasi harus dipandang sebagai fungsi dari tingkat pengendalian stakeholder atas sumber daya yang dibutuhkanorganisasi Watts dan Zimmerman (1986). Ketika para stakeholder berupaya untuk mengendalikan sumber daya organisasi, maka orientasinya adalah untuk meningkatkan kesejahteraan mereka. Kesejahteraan tersebut diwujudkan dengan semakin tingginya return yang dihasilkan oleh organisasi.Dalam konteks ini, para stakeholder berkepentingan untuk mempengaruhi manajemen dalam proses pemanfaatan seluruh potensi yang dimiliki oleh organisasi. Karena hanya dengan pengelolaan yang baik dan maksimal atas seluruh potensi inilah organisasi akan dapat menciptakan value added untuk kemudian mendorong kinerja keuangan perusahaan yang merupakan orientasi para stakeholder dalam mengintervensi manajemen. 


\subsubsection{Human Capital Theory}

Human Capital Theory dikembangkan oleh Becker (1964) yang mengemukakan bahwa investasi dalam pelatihan dan untuk meningkatkan humancapital adalah penting sebagai suatu investasi dari bentuk-bentuk modal lainnya. Tindakan strategis membutuhkan seperangkat sumber daya fisik, keuangan, human atau organisasional khusus, sehingga keunggulan kompetitif ditentukan oleh kemampuannya untuk memperoleh dan mempertahankan sumber daya, Wernerfelt (1984).

\subsection{Penelitian Terdahulu}

Performa perusahaan adalah fungsi dari kemampuan perusahaan untuk mendapatkan keuntungan dan mengelola sumber daya dalam beberapa cara yang berbeda untuk mengembangkan keuntungan kompetitif.

Bontis et al. (2000) menyatakan bahwa secara umum, para peneliti mengidentifikasi tiga konstruk utama dari modal intelektual, yaitu: human capital (HC), structural capital (SC), dan customer capital (CC). Menurut Bontis et al. (2000), secara sederhana HC merepresentasikan individual knowledge stock suatu organisasi yang direpresentasikan oleh karyawannya. HC merupakan kombinasi dari genetic inheritance; education; experience; and attitude tentang kehidupan dan bisnis.

Bontis et al. (2000) mengidentifikasi modal intelektualsebagai seperangkat sumber daya tak berwujud(kemampuan dan kompetensi) yang menggerakkanorganisasi untuk menciptakan kinerja dan nilai perusahaan.Lebih lanjut Bontis et al. (2000) menyebutkan bahwa SC meliputi seluruh nonhuman storehouses of knowledge dalam organisasi. Termasuk dalam hal ini adalah database, organizational charts, process manuals, strategies, routines dan segala hal yang membuat nilai perusahaan lebih besar dari nilai materialnya. Customer Capital (CC) merupakan pengetahuan yang melekat dalam marketing channels dan customer relationship dimana suatu organisasi mengembangkan hal tersebut melalui proses berbisnis Bontis et al.(2000).

\section{Value added intellectual coefficients (VAIC ${ }^{\mathrm{TM}}$ )}

Hubungan antara modal intelektual $\left(\mathrm{VAIC}^{\mathrm{TM}}\right)$ dengan kinerja keuangan telah dibuktikan secara empiris oleh Firer dan Williams (2003), Belkaoui (2003) dan Tan et al. (2007) yang membuktikan modal intelektual berpengaruh positif pada kinerja keuangan. Salah satu area yang menarik perhatian akademisi maupun praktisi adalah terkait dengan kegunaan modal intelektual sebagai salah satu alat untuk menentukan nilai perusahaan Edvinsson dan Malone (1997). Penelitian Chen et al. (2005) membuktikan bahwa terdapat pengaruh positif modal intelektual terhadap nilai pasar dan kinerja perusahaan

Di Indonesia penelitian tentang modal intelektual diantaranya telah dilakukan oleh Astuti dkk (2005), Ulum dkk. (2008), Sianipar (2009) dan Solikhah dkk. (2010) yang menemukan bahwa modal intelektual berpengaruh positif pada kinerja keuangan, sedangkan penelitian Kuryanto dan Syafruddin (2008) serta Yuniasih dkk. (2010) tidak berhasil membuktikan bahwa modal intelektual berpengaruh positif pada nilai pasar perusahaan.

\subsection{Hipotesis}

Perumusan hipotesis penelitian ini

Ho1 : VACA berpengaruh tidak signifikan pada kinerja perusahaan perdagangan, jasa dan investasi di Bursa Efek Indonesia (BEI).

Ha1 : VACA berpengaruh signifikan pada kinerja perusahaan perdagangan, jasa dan investasi di BEI.

Ho2 : VAHU berpengaruh tidak signifikan pada kinerja perusahaan perdagangan, jasa dan investasi di Bursa Efek Indonesia (BEI). 
Ha2 : VAHU berpengaruh signifikan pada kinerja perusahaan perdagangan, jasa dan investasi di BEI

Ho3 : STVA berpengaruh tidak signifikan pada kinerja perusahaan perdagangan, jasa dan investasi di Bursa Efek Indonesia (BEI).

Ha3 : STVA berpengaruh signifikan pada kinerja perusahaan perdagangan, jasa dan investasi di BEI.

Ho4 : VACE, VAHC dan STVA berpengaruh tidak signifikan pada kinerja perusahaan perdagangan, jasa dan investasi di Bursa Efek Indonesia (BEI).

Ha4 : VACE, VAHC dan STVA berpengaruh signifikan pada kinerja perusahaan perdagangan, jasa dan investasi di BEI.

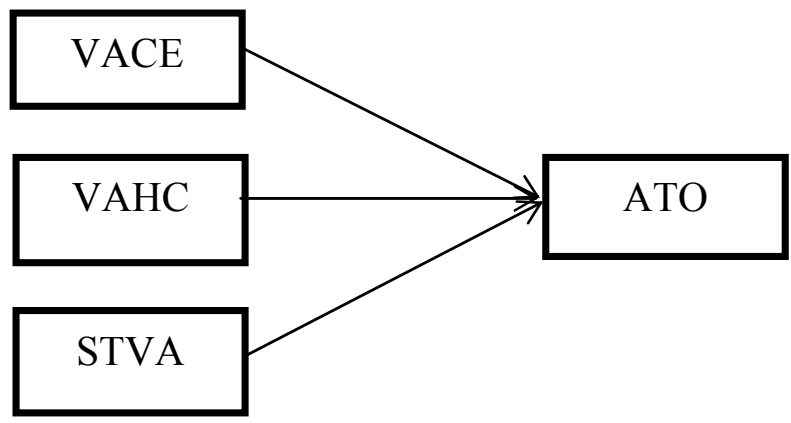

III. Metodologi Penelitian.

3.1. Jenis dan Sumber Data.

Penelitian ini menggunakan data kuantitatif. Data kuantitatif yang dimaksud di ambil dari laporan keuangan perusahaan manufaktur yang terdaftar di BEI periode tahun 2009 sampai dengan 2012.

Sumber data penelitian ini adalah data sekunder. Data sekunder penelitian ini berupa laporan keuangan yang dipublikasikan, yang diperoleh melalui (BEI).

\subsection{Populasi dan Sampel}

Populasi dalam penelitian ini adalah perusahaan-perusahaan yang terdaftar di BEI untuk periode tahun 2009 sampai dengan 2012. Dari Populasi, dipilih 58 sampel perusahaan, sehingga menjadi 232 pengamatan. Sample dipilih metode purposive samplingdenganteknik Judgement Samplingdengan kriteria sebagai berikut:

1.Perusahaan telah beroperasi dan terdaftar di BEI antara tahun 2009 sampai dengan 2012.

2.Perusahaan telah menerbitkan laporan keuangan per 31 Desember secara lengkap dan diaudit untuk tahun 2009 sampai dengan 2012.

3.Memiliki data yang lengkap terkait dengan variabel-variabel yang dibutuhkan dalam penelitian ini.

\subsection{Definisi Operasional Variabel Penelitian.}

Variabel independen dalam penelitian ini adalah modal intelektual. Modal intelektual diukur secara tidak langsung dengan menilai efisiensi dari nilai tambah (value added) sebagai hasil dari kemampuan intelektual perusahaan (Value Added Intellectual Coefficient VAIC ${ }^{\mathrm{TM}}$ ).

Komponen utama dari VAIC ${ }^{\mathrm{TM}}$ dapat dilihat dari sumber daya perusahaan, yaitu physical capital (VACA-value added capital employed), human capital (VAHU-value added human capital), dan structural capital (STVA-structural capital value added).Pengukuran modal intelektual menggunakan tiga proksi, yaitu: 
1. Value Added Capital Coefficient (VACA)

VACA adalah perbandingan antara value added (VA) dengan modal fisikyang bekerja (CA).

Rasio ini adalah sebuah indikator untuk VA yang dibuat oleh satu unit modal fisik dengan

formula sebagai berikut:

$\mathrm{VACA}=\mathrm{VA} / \mathrm{CA}$

VA dihitung sebagai selisih antara output dan input

$\mathrm{VA}=\mathrm{OUT}-\mathrm{IN}$

Dimana:

OUT $=$ Output: total penjualan dan pendapatan lain.

$\mathrm{IN}=$ Input: beban penjualan dan biaya-biaya lain (selain beban karyawan).

Value Added (VA) juga dapat dihitung dari akun-akun perusahaan sebagai berikut:

$\mathrm{VA}=\mathrm{OP}+\mathrm{EC}+\mathrm{D}+\mathrm{A}$

Dimana:

$\mathrm{OP} \quad=$ operating profit (laba operasi);

$\mathrm{EC}=$ employee costs (beban karyawan);

$\mathrm{D}=$ depreciation (depresiasi);

$\mathrm{A}=$ amortization (amortisasi)

2. The Human Capital Coefficient (VAHU)

VAHU adalah seberapa besar VA dibentuk oleh pengeluaran rupiah pekerja. Hubungan antara VA dan HC mengindikasikan kemampuan HC membuat nilai pada sebuah perusahaan. Jadi hubungan antara VA dan HC mengindikasikan kemampuan HC membentuk nilai dalam sebuah perusahaandengan formula sebagai berikut:

$\mathrm{VAHU}=\mathrm{VA} / \mathrm{HC}$

Dimana:

Human Capital $=$ total Expenditure on Employees

3. Structural Capital Coefficient (STVA)

STVA menunjukkan kontribusi modal struktural (SC) dalam pembentukan nilai. Dalam model

Pulic, SC merupakan VA dikurangi HC. Kontribusi HC pada pembentukan nilai lebih besar kontribusi SC dengan formula sebagai berikut:

$\mathrm{STVA}=\mathrm{SC} / \mathrm{VA}$

Dimana:

Structural Capital $=$ Value added - Human capital

Hasilnya yaitu the $V A I C^{\mathrm{TM}}$, yaitu sebagai berikut:

VAIC ${ }^{\mathrm{TM}}=\mathrm{VACA}+\mathrm{VAHU}+\mathrm{STVA}$

Variabel dependen dalam penelitian ini adalah kinerja perusahaan. Pengukuran kinerja perusahaan itu sendiri menggunakan Asset Turn Over(ATO). ATO adalah rasio untuk mengukur kemampuan aset perusahaan untuk memperoleh pendapatan, makin cepat aset perusahaan berputar makin besar pendapatan perusahaan tersebut. Formulasinya adalah

ATO $=\frac{\text { Total Pendapatan }}{\text { Total Aset }}$

\subsection{Metode Analisis.}

Pengujian hipotesis dalam penelitian ini menggunakan analisis regresi berganda, dengan $\alpha=5 \%$. Persamaan yang digunakan adalah : 


$$
\mathrm{ATO}=\mathrm{a}+\beta 1 \mathrm{VACA}+\beta 2 \mathrm{VAHU}+\beta 3 \mathrm{STVA}
$$

Pengujian asumsi klasik untuk model regresi dilakukan sebagai berikut:

\section{Uji Normalitas}

Uji normalitas bertujuan untuk menguji variabel pengganggu atau residual memiliki distribusi normal. Uji yang dapat digunakan adalah uji statistik non parametrik Kolmogorov SmirnovGhozali (2009).

\section{Uji Autokorelasi}

Uji autokorelasi bertujuan menguji apakah dalam model regresi linear ada korelasi antara kesalahan pengganggu pada periode $\mathrm{t}$ dengan kesalahan pengganggu pada periode $\mathrm{t}-1$ (sebelumnya) Ghozali(2009)

\section{Uji Multikolinearitas}

Variabel bebas yang saling berkorelasi akan menyebabkan variabel tersebut tidak orthogonal yaitu nilai korelasi antara sesama variabel bebas tidak sama dengan nol. Multikolinearitas dapat diketahui ada atau tidaknya dalam sebuah model.

\section{Uji Heteroskedastisitas}

Uji Heteroskedastisitas bertujuan menguji apakah model regresi terjadi ketidaksamaan variance dari residual satu pengamatan ke pengamatan yang lain. Jika variance dari residual dari satu pengamatan ke pengamatan lain tetap disebut homoskedastisitas. Uji heteroskedastisitas menggunakan uji Glejser. Uji Glejser meregres nilai absolut residual terhadap variabel independen. Apabila nilai probabilitas koefisien regresi tersebut hasilnya signifikan di bawah tingkat signifikansi 0,05 , maka dapat dinyatakan terjadi heteroskedastisitas Ghozali(2009).

\section{ANALISIS DAN PEMBAHASAN}

\subsection{Analisis.}

\subsubsection{Uji Asumsi Klasik.}

\section{Uji Normalitas.}

\begin{tabular}{|c|c|c|}
\hline \multicolumn{3}{|c|}{ One-Sample Kolmogorov-Smirnov Test } \\
\hline & & $\begin{array}{c}\text { Unstandardized } \\
\text { Residual }\end{array}$ \\
\hline $\mathrm{N}$ & & 232 \\
\hline Normal Parameters ${ }^{a, b}$ & Mean & .0000000 \\
\hline & Std. Deviation & 1.40791657 \\
\hline Most Extreme Differences & Absolute & .064 \\
\hline & Positive & .050 \\
\hline & Negative & -.064 \\
\hline Kolmogorov-Smirnov Z & & .972 \\
\hline Asymp. Sig. (2-tailed) & & .301 \\
\hline
\end{tabular}
a. Test distribution is Normal.
b. Calculated from data.

Pada Tabel 1 berdasarkan uji non parametrik Kolmogorov Smirnov, ditemukan tingkat signifikansi 0.301>0.05, sehingga disimpulkan bahwa data terdistribusi normal. 


\section{Uji Autokorelasi.}

Nilai Durbin Watson yang diperoleh adalah 1.986, dapat disimpulkan tidak terjadi autokorelasi pada data penelitian ini.

\begin{tabular}{|l|r|r|r|r|r|}
\hline \multicolumn{1}{|c|}{ Model } & \multicolumn{1}{|c|}{ R } & R Square & $\begin{array}{c}\text { Adjusted R } \\
\text { Square }\end{array}$ & $\begin{array}{c}\text { Std. Error of the } \\
\text { Estimate }\end{array}$ & Durbin-Watson \\
\hline 1 & $.395^{\mathrm{a}}$ & .156 & .145 & 1.41715 & 1.986 \\
\hline
\end{tabular}

a. Predictors: (Constant), VACA, VAHU, STVA

b. Dependent Variable: ATO

\section{Uji Multikolinearitas.}

Hasil pengujian menunjukkan bahwa semua nilai Tolerance dan nilai VIF dari variabel independen memiliki nilai Tolerance $>0,10$ dan nilai VIF $<10$. Maka dapat disimpulkan bahwa antar variabel independen tidak terjadi efek multikolinearitas.

\begin{tabular}{|ll|r|r|r|r|}
\hline \multirow{2}{*}{} & & & & \multicolumn{2}{|c|}{ Collinearity Statistics } \\
\cline { 5 - 6 } Model & & \multicolumn{1}{c|}{$\mathrm{t}$} & \multicolumn{1}{c|}{ Sig. } & Tolerance & \multicolumn{1}{c|}{ VIF } \\
\hline 1 & (Constant) & -12.541 & .000 & & \\
& VACA & 1.850 & .066 & .656 & 1.524 \\
& VAHU & 3.196 & .002 & .656 & 1.524 \\
& STVA & -2.679 & .008 & .985 & 1.015 \\
\hline
\end{tabular}

\section{Uji 4.Heteroskedastisitas.}

Hasil Uji Glesjer, ditemukan bahwa tingkat signifikansi setiap variabel independen terhadap logaritma natural residual error berada diatas 0.05 , sehingga disimpulkan bahwa varians data penelitian adalah homoskedastisitas.

\begin{tabular}{|c|c|c|c|c|c|c|}
\hline \multicolumn{7}{|c|}{ Coefficients $^{\mathrm{a}}$} \\
\hline \multirow{2}{*}{\multicolumn{2}{|c|}{ Model }} & \multicolumn{2}{|c|}{ Unstandardized Coefficients } & \multirow{2}{*}{$\begin{array}{c}\text { Standardized } \\
\text { Coefficients } \\
\text { Beta }\end{array}$} & \multirow[b]{2}{*}{$\mathrm{t}$} & \multirow[b]{2}{*}{ Sig. } \\
\hline & & $\mathrm{B}$ & Std. Error & & & \\
\hline \multirow[t]{4}{*}{1} & (Constant) & 1.043 & .085 & & 12.202 & .000 \\
\hline & VACA & -.056 & .074 & -.063 & -.766 & .444 \\
\hline & VAHU & .004 & .014 & .022 & .265 & .791 \\
\hline & STVA & -.016 & .049 & -.022 & -.332 & .740 \\
\hline
\end{tabular}

a. Dependent Variable: ABS_RES 


\subsubsection{Uji Regresi Linear Berganda.}

Persamaan regresi penelitian ini adalah :

ATO $=-\mathbf{1 . 5 7 7}+0.200 \mathrm{VACE}+0.065 \mathrm{VAHC}-0.195 \mathrm{VASC}$

\subsubsection{Koefisien Korelasi dan Determinasi.}

Terdapat hubungan yang lemah antara variabel dependen dengan variabel independen dengan nilai korelasi (R) ditemukan sebesar 0.395. Sedangkan kontribusi variabel independen untuk menjelaskan model variabel dependen adalah sebesar 15,6\% dan sisanya dijelaskan oleh variabel lain yang tidak dimasukkan dalam penelitian ini.

\begin{tabular}{|l|r|r|r|c|}
\hline & & & \multicolumn{4}{|c|}{ Model Summary $^{\text {b }}$} \\
Model & $\mathrm{R}$ & $\mathrm{R}$ Square & \multicolumn{1}{c|}{$\begin{array}{c}\text { Adjusted R } \\
\text { Square }\end{array}$} & $\begin{array}{c}\text { Std. Error of the } \\
\text { Estimate }\end{array}$ \\
\hline 1 & $.395^{\mathrm{a}}$ & .156 & .145 & 1.41715 \\
\hline
\end{tabular}
a. Predictors: (Constant), VACE, VAHC, STVA
b. Dependent Variable: ATO

\subsubsection{Uji Signifikansi Simultan (Uji Statistik F).}

Secara bersama - sama, variabel VACE, VAHC dan STVA berpengaruh terhadap kinerja perusahaan.

\begin{tabular}{|ll|r|r|r|r|r|}
\hline Model & & Sum of Squares & \multicolumn{1}{|c|}{ df } & Mean Square & \multicolumn{1}{c|}{ F } & Sig. \\
\hline 1 & Regression & 84.868 & 3 & 28.289 & 14.086 & $.000^{a}$ \\
& Residual & 457.895 & 228 & 2.008 & & \\
& Total & 542.762 & 231 & & & \\
\hline
\end{tabular}

a. Predictors: (Constant), VACE, VAHC, STVA

b. Dependent Variable: ATO

\subsection{Pembahasan.}

\begin{tabular}{|c|c|c|c|c|c|c|}
\hline \multicolumn{7}{|c|}{ Coefficients $^{\mathrm{a}}$} \\
\hline \multirow{2}{*}{\multicolumn{2}{|c|}{ Model }} & \multicolumn{2}{|c|}{ Unstandardized Coefficients } & \multirow{2}{*}{$\begin{array}{c}\text { Standardized } \\
\text { Coefficients } \\
\text { Beta }\end{array}$} & \multirow[b]{2}{*}{$\mathrm{t}$} & \multirow[b]{2}{*}{ Sig. } \\
\hline & & $\mathrm{B}$ & Std. Error & & & \\
\hline \multirow[t]{4}{*}{1} & (Constant) & -1.577 & .126 & & -12.541 & .000 \\
\hline & VACA & .200 & .108 & .139 & 1.850 & .066 \\
\hline & VAHC & .065 & .020 & .240 & 3.196 & .002 \\
\hline & STVA & -.195 & .073 & -.164 & -2.679 & .008 \\
\hline
\end{tabular}

a. Dependent Variable: ATO 


\subsubsection{Uji Hipotesis 1 .}

Hasil uji statistik t menunjukkan bahwa Ho diterima, VACA atau modal fisiktidak berpengaruh terhadap kinerja perusahaanperdagangan, jasa dan investasi di BEI, dengan tingkat signifikansi $0.066>0.05$

Hal ini mengindikasikan bahwa telah terjadi pergeseran paradigma, efisiensi modal fisik bukan lagi merupakan modal utama untuk menciptakan nilai dalam menghasilkan kinerja perusahaan yang lebih baik dalam hal peningkatan pendapatan perusahaan. analisis keunggulan bersaing yang dikenal dengan pendekatan berbasis sumber daya (resource-based view of thefirm/RBV). Ini dicirikan oleh keunggulan pengetahuan (knowledge/learning economy) atau perekonomian yang mengandalkan aset-aset tak berwujud(intangible assets).

Hasil penelitian ini sejalan dengan penelitian Firer and Stainbank (2003) pada perusahaan di Afrika Selatan yang menujukkan bahwa terdapat hubungan antara modal intelektual dengan profitabilitas, tapi tidak terdapat hubungan yang mendukung hipotesis adanya hubungan antara modal intelektual dengan kinerja perusahaan. Demikian juga dengan penelitian Kuryanto (2008), menunjukkan hasil yaitu modal intelektual tidak berpengaruh terhadap kinerja keuangan perusahaan. Berbeda dengan hasil penelitian Firer dan Williams (2003) yang menyatakan physical capital merupakan faktor yang paling signifikan berpengaruh terhadap kinerja perusahaan di Afrika Selatan.

\subsubsection{Uji Hipotesis 2 .}

Uji statistik t menunjukkan bahwa Ho ditolak, VAHC atau modal karyawan berpengaruh signifikan terhadap kinerja perusahaan perdagangan, jasa dan investasi di BEI, dengan tingkat signifikansi $0.002<0.05$.

Hasil uji hipotesis ini sejalan dengan Human Capital Theory yangberpendapat bahwa investasi sumber daya manusia mempunyai pengaruh yang besar terhadap peningkatan produktivitas. Peningkatan produktivitas tenaga kerja ini dapat didorong melalui pendidikan dan pelatihan, Becker (1964). Hal ini mengindikasikan bahwa modal karyawan memberikan kontribusi pada setiap rupiah yang diinvestasikan dalam $\mathrm{HC}$ terhadap value added suatu organisasi.Perusahaan perdagangan, jasa dan investasi menyadari bahwa modal karyawan merupakan potensi perusahaan dalam hal untuk membangun pasar yang kuat melalui pendapatan. Dengan kata lain, semakin kompeten karyawan perusahaan semakin cepat perputaran kas, sejumlah kas yang ditanamkan dalam bisnis, dikembalikan melalui peningkatan penjualan. Dalam hal ini, bukan sehubungan dengan laba tapi lebih pada arus kas. Jika perputaran penjualan tinggi, maka hanya sedikit kas yang akan disediakan untuk menjaga agar bisnis tetap berjalan, sehingga akan lebih mudah bagi perusahaan untuk melakukan ekspansi dan bersaing.

Hasil penelitian ini mendukung pandangan teori stakeholder, perusahaan memiliki stakeholders, bukan sekedar shareholder. Dalam konteks ini, karyawan telah berhasil ditempatkan dan menempatkan diri dalam posisi sebagai stakeholders perusahaan, sehingga mereka memaksimalkan intellectual ability-nya untuk menciptakan nilai bagi perusahaan. Pembuktian ini juga berhasil mendukung teori stakeholder. Dimana dalam teoritersebut dinyatakan bahwa seluruh pemangku kepentingan dalam perusahaan berusahamemaksimalkan kesejahteraan mereka dengan memainkan perannya sebagai kontrol ataspengelolaan seluruh sumber daya yang dimiliki perusahaan.

Hasil penelitian ini mendukung penelitianyang dilakukan Tan et al. (2007) di Bursa Efek Singapore menunjukkan bahwa IC (VAIC ${ }^{\text {TM}}$ )berhubungan secara positif dengan kinerja perusahaan an kinerja perusahaan di masamendatang. Juga selaras dengan Tan et al. (2005), 
Bontis et al.(2001) dan Belkaoui (2003) yang menyatakanbahwa IC (VAICTM) berpengaruh positif terhadap kinerja keuangan perusahaan.

\subsubsection{Uji Hipotesis 3}

Uji statistik $\mathrm{t}$ menunjukkan bahwa Ho ditolak, STAVA atau modal struktural berpengaruh signifikan negative terhadap kinerja perusahaan perdagangan, jasa dan investasi di BEI, dengan tingkat signifikansi $0.008<0.05$.

Hasil penelitian ini mendukung penelitian Bontis (2000) yang menyatakan bahwa meskipun sumber daya manusia memiliki tingkat intelektualitas yang tinggi, sedangkan organisasi tidak memiliki sistem dan prosedur yang baik, maka modal intelektualtidak dapat mencapai kinerja secara optimal dan potensi yang ada tidak dapat dimanfaatkan secara maksimal. Dengan kata lain hipotesis 1 berkaitan dengan hipotesis 2. Penelitian ini juga sejalan dengan penelitian Margaretha dan Rakhman (2006), menyimpulkan bahwa besarnya modal intelektual yang dimiliki perusahaan memiliki pengaruh positif terhadap kinerja keuangan perusahaan.

Hasil uji menunjukkan bahwa jika modal struktural menurun maka Asset Turn Over naik, menurunnyateknologi yang digunakan perusahaan, proses, data perusahaan akan meningkatkan perputaran kas melalui penjualan.Penjelasan akan hal ini adalah jika Asset Turn Over perusahaan-perusahaan perdagangan, jasa dan investasi di BEImeningkat maka terjadi overtrading dimana terlalu banyak pendapatan penjualan dengan sedikit investasi pada modal structural perusahaan. Apabila Asset Turn Over menurun hal ini mengindikasikan perusahaan overinvested pada modal structural.

\subsubsection{Uji Hipotesis 4}

Uji statistik t menunjukkan bahwa Ho ditolak, VACE, VAHC dan STAVA berpengaruh signifikan terhadap kinerja perusahaan perdagangan, jasa dan investasi di BEI.

Sejalan dengan Resources Based Theory yangmengemukakan bahwa sumber daya perusahaan adalah heterogen, tidak homogen,jasa produktif yang tersedia berasal dari sumber daya perusahaan yangmemberikan karakter unik bagi tiap-tiap perusahaan. Asumsi RBV yaitu bagaimana perusahaan dapat bersaing dengan perusahaan lain untuk mendapatkan keunggulan kompetitif dengan mengelola sumber daya yang dimilikinya sesuai dengan kemampuan perusahaan. Pendekatan RBV menyatakan bahwa perusahaan dapat mencapai keunggulan bersaing yang berkesinambungan dan memperoleh keuntungan superior dengan memiliki atau mengendalikan aset-aset strategis baik yang berwujud maupun yang tidak berwujud.

Konsensus yang berkembang dalam konteks teori stakeholder adalah bahwa laba akuntansi hanyalah merupakan ukuran return bagi pemegang saham (shareholder), sementara valueadded adalah ukuran yang lebih akurat yang diciptakan oleh stakeholders dan kemudian didistribusikan kepada stakeholders yang sama Meek dan Gray (1988).Value added yang dianggap memiliki akurasi lebih tinggi dihubungkan dengan return yang dianggap sebagai ukuran bagi shareholder. Sehingga dengan demikian keduanya (value added dan return) dapat menjelaskan kekuatan teori stakeholder dalam kaitannya dengan pengukuran kinerja organisasi.

Hasil uji hipotesis ini konsisten terhadap temuan Tan et al. (2007) dan Chen et al. (2005). Bukti yang disajikan oleh Tan et al. (2007) dan Chen et al. (2005) menyatakan bahwa tiga komponen VACA, VAHU, dan STVA secara statistik signifikan untuk menjelaskan konstruk VAIC dan juga signifikan berpengaruh terhadap kinerja keuangan perusahaan.

\section{Kesimpulan.}

Perusahaan-perusahaan perdagangan, jasa dan investasi yang terdaftar di BEI menganggap bahwa modal intelektual merupakan hal penting, sebagai penggerak nilaimenuju 
keunggulan kompetitif. Kesimpulan ini berdasarkan hasil penelitian yang menunjukkan adanya hubungan yang signifikan antara modal intelektual, dalam hal ini modal karyawan dan modal struktural dengan kinerja perusahaan.

Nilai informasi dalam laporan keuangan tradisional sehubungan dengan penggerak yang menghasilkan nilai, adalah modal karyawan dan modal struktural. Kedua komponen modal intelektual ini dinilai yang memberikan kontribusi terhadap kinerja perusahaan. Komponen modal karyawan merupakan komponen modal intelektual yang dinilai memberikan kontribusi yang paling tinggi terhadap penciptaan nilai kompetitif. Nilai bisa dihasilkan dari aset tak berwujud, memiliki kemampuan untuk menciptakan nilai. Hal itu mendorong perusahaanperusahaan untuk membuat dan mempertahankan keuntungan kompetitif melalui pengelolaan karyawan sebagai strategi sumber daya yang kritikal.

\section{Saran}

Penelitian selanjutnya dapat memasukkan seluruh biaya karyawan untuk menghitung VAHU seperti biaya gaji dan upah, biaya pelatihan, biaya studi dan bonus agar hasil lebihbaik, karena dalam penelitian ini, nilai VAHU yang dihitung hanya biaya gaji dan tunjangan saja. Selain itu dapat juga memasukan research and development dalam perhitungan modal intelektual.

Penelitian selanjutnya dapat menambah obyek penelitian pada berbagai jenis industri serta mengklasifikasikan ke dalam high-tech industri, low-tech industry. Diharapkan hasil penelitian tersebut dapat memberikan gambaran yang lebih dalam tentang modal intelektual, karena beberapa penelitian menunjukkan bahwa modal intelektual untuk masing-masing industri berbeda-beda.

Menambahkan ukuran perusahaan sebagai variabel kontrol terhadap kinerja keuangan.Karenaukuran perusahaan mempengaruhi perusahaan dalam memperhitungkan modal intelektual.

\section{DAFTAR PUSTAKA}

Abeysekera, I. and Guthrie, J. 2005. An Empirical Investigation Of Annual Reporting Trends Of Intellectual Capital In Sri Lanka, Critical Perspectives on Accounting, Vol. 16 No. 3, pp. 151-63.

Astuti, Partiwi Dwi dan Arifin Sabeni. 2005. Hubungan Intellectual Capital dan Business Performance dengan Diamond Specification: Sebuah Perspektif Akuntansi. Prosiding SNA VIII Solo, Semptember, halaman 694-707

Barney, Jay B. 2001. Resource-Based Theories of Competitive Advantage: A Ten Year Retrospective on the Resource-Based View. Journal of Management 27, pp 643-650.

Belkaoui, Riahi A. 2003. Intellectual Capital And Firm Performance Of Us Multinational Firms: A Study of The Resource-Based And Stakeholder Views. Journal of Intellectual Capital, 4(2), 215-226.

Becker, G.S. 1964.Human Capital : A Theoretical \& Empirical Analysis. 3d Edition.Columbia University Press. New York

Bontis, Nick. 1999. Managing Organizational Knowledge by Diagnosing Intellectual Capital: Framing andAdvancing the State of the Field. International Journal of Technology Management, 18, 5/6/7/8, 433-462.

Bontis, Nick. 2000. Assessing Knowledge Assets: A Review of the Models used to measure intellectual. capital. 
Bontis, N., W.C.C. Keowand S. Richardson. 2000. Intellectual Capital and Business Performance in Malaysian Industries.Journal of Intellectual Capital. Vol. 1, No. 1: 85100.

Bontis, Nick. 2001. Assessing Knowledge Assets: a Review of the Models Used to Measure Intellectual Capital. International Journal of Management Reviews, 3, 1, 41-60

Bontis, Nick, Crossan, M. and J. Hulland. 2001. Managing an Organizational Learning System by Aligning Stocks and Flows, Journal of Management Studies, forthcoming.

Bozzolan, S., F. Favotto, \& F. Ricceri. 2003. Italian Annual Intellectual Capital Disclosure: An Empirical Analysis. Journal of Intellectual Capital. 4 Iss 4, 543-558..

Chen, M.C., S.J. Cheng, Y. Hwang. 2005. An Empirical Investigation Of The Relationship Between Intellectual Capital And Firms' Market Value And Financial Performance. Journal of Intellectual Capital.Vol. 6 No. 2. pp. 159-176.

Edvinsson, L. 1997. Developing intellectual capital at Skandia. Long Range Planning. Vol. 30 No. 3, pp. 366-73.

Edvinsson, L. and Malone, M. 1997. Intellectual Capital: Realizing Your Company's True Value by Finding Its Hidden Brain-power. New York: Harper Collins, NY.

Firer, S. and Stainbank, L. 2003. Testing The Relationship Between Intellectual Capital And A Company $\square S$ Performance: Evidence from South Africa. Journal of Meditari Accountancy Research, 11(1): 25-44.

Firer, Steven., dan S. Mitchell Williams. 2003. Intellectual Capital and Traditional Measures of Corporate Performance.Journal of Intellectual Capital. Vol. 4, No. 3: 348-360.

Ghozali, Imam. 2009. Aplikasi Analisis Multivariate dengan Program SPSS. Semarang: Badan Penerbit Universitas Diponegoro.

Guthrie, J. 2001. TheManagement, Measurement And The Reporting Of Intellectual Capital. Journal of Intellectual Capital, Vol. 2 No. 1, p. 27

Jaluanto dan Kurniyawan. 2012. Studi Intellectual Capital terhadap Nilai Pasar dan Kinerja Keuangan Perusahaan Makanan dan Minum (Terdaftar pada Bursa Efek Indonesia Tahun 2009-2010). Serat Acitya-Jurnal Ilmiah, UNTAG Semarang, hal 37-46.

Kuryanto, Benny dan Muchamad Syafruddin. 2008. Pengaruh Modal Intelektual terhadap Kinerja Perusahaan, makalah dipresentasikan, Simposium Nasional Akuntansi XI, Ikatan Akuntan Indonesia Kompartemen Akuntan Pendidik, pp. 1-30.

Margaretha, Farah dan Rakhman, Arief. 2006. Analisis Pengaruh Intellectual Capital Terhadap Market Value Dan Financial Performanve Perusahaan Dengan Metode Value Added Intellectual Coefficient. Jurnal Bisnis dan Akuntansi, 8(2):199-217.

Meek, Gary K., and Sidney J. Gray. 1998. The Value added statement: An innovation for the U.S. companies. Accounting Horizons, June: 73-81.

Organization for Economic Cooperation and Development (OECD).1999. OECD symposium on measuring and reporting of intellectual capital, Amsterdam, OECD, Paris

Pulic, A. 1998. Measuring the performance of intellectual potential in knowledge economy, paper presented at the $2^{\text {nd }}$ McMaster World Congress on Measuring and Managing Intellectual Capital by the Austrian Team for Intellectual Potential.

Pulic., A. 2000. VAIC - An Accounting Tool for IC Management. International Journal ofTechnology Management, Vol 20 No. 5.

Petty, P. And Guthrie, J. 2000. The Intellectual Capital Literature Review: Measurement, Reporting And Management.Journal of Intellectual Capital,Vol.1 No.2, pp.155-175. 
Purnomosidhi, Bambang. 2006. Praktik Pengungkapan Modal Intelektual Pada Perusahaan Publik di BEJ. Jurnal Riset Akuntansi Indonesia. Vol. 9 No. 1 Hal 20

Roos, G., Roos, J., Edvinsson, L., and Dragonetti, N.C. 1997. Intellectual Capital - Navigating In The New Business Landscape. New York: New York University Press.

Sawarjuwono, Tjiptohadi. dan Kadir, Agustine Prihatin. 2003. Intellectual Capital:

Perlakuan, Pengakuan, Pengukuran dan Pelaporan (Sebuah Library Research). Jurnal Akuntansi \& Keuangan Vol 5 No. 1, Hal 35-57.

Stewart, T. A. 1994. Your Company's Most Valuable Asset: Intellectual Capital. Fortune, (October): 68-74.

Stewart, Thomas. 2002. Modal Intelektual: Kekayaan Baru Organisasi. Jakarta: PT. Elex Media Komputindo

Tan, H.P., D. Plowman, P. Hancock. 2007. Intellectual Capital and Financial Returns ofCompanies. Journal of Intellectual Capital.Vol. 8 No. 1. pp. 76-95.

Ulum,Ihyaul.2007. Pengaruh Intellectual Capital terhadap Kinerja Keuangan;Suatu Analisis dengan Metode PLS.Proceeding SNA XI.Pontianak.

Ulum, Ihyatul. 2008. Intellectual Capital Sector Perbankan Di Indonesia. Jurnal Akuntansi dan Keuangan Vol. 10 No.2 hal 77-84.

Ulum, Ihyaul. 2012. Investigasi Hubungan antara Kinerja Modal Intelektual dan Praktik Pengungkapannya dalam Laporan Tahunan Perusahaan. Jurnal Ekonomi Bisnis, volume 17, no 1, hlm 36-45. ISSN: 0853-7283

Watts, R. L. and Zimmerman, J.L. 1986. Positive Accounting Theory. London Prentice/Hall International Inc.

Wernerfelt, B. 1984. AResource-Based View Of The Firm, Strategic Management Journal. Vol. 5. No. 2. pp. 171-180.

Yuniasih, Ni Wayan, Dewa G.Wirama, dan Dewa N. Badera. 2010. Eksplorasi Kinerja Pasar Perusahaan: Kajian Berdasarkan Modal Intelektual. Makalah Disampaikan dalam Simposium Nasional Akuntansi XIII. Purwekerto: 13-15 Oktober. 